\title{
Morphometric Study of Suprascapular Notch and Its Variations in Dried Human Scapulae
}

\author{
Kamal D. Pawar, Sushama K. Chavan, Mohini M. Joshi
}

\section{ABSTRACT}

The study was undertaken to see the variation of the suprascapular notch. The notch is present on the superior border of the scapula near the root of coracoid process. It is roofed by the superior transverse ligament and is converted into foramen for the passage of suprascapular nerve. The study was carried out on 121 scapulae in the department of Anatomy RMC Loni, Ahmednagar. The parameters included in the study were presence of notch, shape of notch, transvers length of notch, edge of notch, ossification of transverse ligament and other finding were also noted. The parameters were measured by Vernier calliper and appropriate statistical tests were applied.

The supra-scapular notch was present in $82.64 \%$ of scapulae. U Deep shaped notch was most common shape followed by $J$ shallow shaped notch. Round edge at the depth of the notch was more common.

The knowledge of suprascapular notch variations is of great importance for surgeons performing suprascapular nerve decompression especially by means of endoscopic techniques. Our anatomical study helps the clinicians before planning a surgery.

Keywords: Suprascapular notch, superior transverse scapular ligament, suprascapular foramen, suprascapular nerve.

Published Online: December 31,2020

ISSN: $2593-8339$

DOI: 10.24018 / ejmed.2020.2.6.473

\section{Dr. Kamal D. Pawar}

Tutor, Department of Anatomy, Rural Medical College, Loni, Maharashtra,India. (rathodhk62@gmail.com)

\section{Dr. Sushama K. Chavan*}

Professor, Department of anatomy, MIMER Medical College, Talegaon Dabhade, Maharashtra, India. (sushamachavan2003@gmail.com)

\section{Dr. Mohini Joshi}

Professor, Deparment of Anatomy, Rural Medical College, Loni,

Maharashtra, India.

(atharvamohini@gmail.com)

*Corresponding Author

\section{INTRODUCTION}

The scapula is a flat triangular bone that lies on the posterolateral aspect of chest wall between the second and the seventh ribs. The suprascapular notch (SSN) is present at the root of coracoid process and at the lateral end of superior border. This notch is converted into a foramen by the superior transverse scapular ligament and serves as a passage for the suprascapular nerve [1].

The suprascapular nerve is commonly susceptible to compression mainly at two major sites i.e., at the level of the suprascapular notch and at the base of the spine of scapula [2]. This suprascapular nerve entrapment syndrome was first described by Kopell and Thompson in 1959 and mentioned that smaller the size of the notch, greater the chance of nerve entrapment [3]. Abduction of the shoulder joint beyond $90{ }^{\circ} \mathrm{C}$ may exert traction on the suprascapular nerve, which leads to its compression against transverse scapular ligament.

The narrow suprascapular notches have been reported in patients with the nerve entrapment. Suprascapular nerve compression may present with vague pain radiating across the scapula, dull shoulder ache, limitations of shoulder joint movements and wasting of supraspinatus and infraspinatus [4]. The suprascapular notch serves as an important landmark during arthroscopic procedures [5]. So, we have decided to study the "Morphometric study of suprascapular notch and its variations in dried human scapulae." which may have an immense help to anatomists, osteologists, anthropologists and orthopedic.

\section{MATERIAL AND METHODS}

The presence of suprascapular notch was studied in 150 dried scapulae of unknown age sex and race, which were collected from the Department of Anatomy Rural medical college Loni. Damaged superior border and decayed scapulae were excluded. The scapulae were divided into right and left (right 65 and left 56). Morphological features of SSN and its variation was observed according to the shape of SSN.The non-metrical parameters of the notch were as follows: Presence or Absence of notch, Shape of the notch, Nature of edge at the depth of the notch and ossification of the transverse scapular ligament. Metrical parameters were transverse width at the upper and middle part of the notch, depth of notch was measured by Vernier calliper in mm. (Fig. 1). Also, transverse, and vertical diameter of the suprascapular foramen with ossified transverse scapular ligament was measured. 


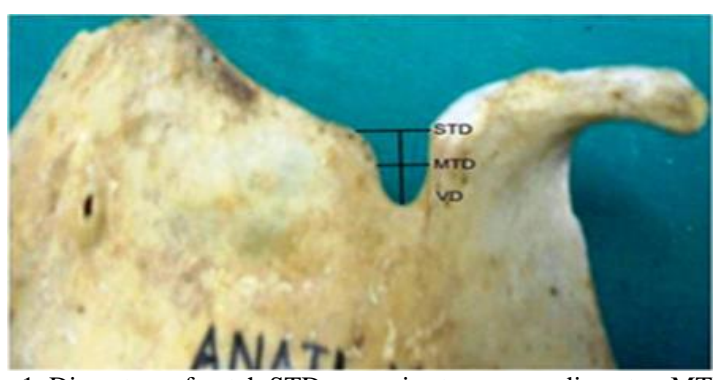

Fig.1. Diameters of notch STD -superior transverse diameter, MTDmiddle transverse diameter, VD- vertical depth.

\section{OBSERVATIONS AND RESULTS}

It is evident from Table I that supra-scapular notch was present in $82.65 \%$ of scapulae.

The supra-scapular notch was present more on right scapulae as compared to left.

TABLE I: PRESENCE OF SUPRA-SCAPULAR NOTCH

\begin{tabular}{|c|c|c|c|c|}
\hline \multirow[b]{2}{*}{ Particulars } & \multicolumn{2}{|c|}{ Side } & \multirow{2}{*}{$\begin{array}{c}\text { No of } \\
\text { [Scapulae } \\
(121)\end{array}$} & \multirow[b]{2}{*}{ Percentage $\%$} \\
\hline & $\begin{array}{c}\mathrm{Rt} \\
(65)\end{array}$ & $\begin{array}{c}\mathrm{Lt} \\
(56)\end{array}$ & & \\
\hline $\begin{array}{l}\text { Presence of } \\
\text { Notch }\end{array}$ & 55 & 45 & 100 & $82.65 \%$ \\
\hline $\begin{array}{c}\text { Absence of } \\
\text { Notch }\end{array}$ & 10 & 11 & 21 & $17.35 \%$ \\
\hline
\end{tabular}

It is evident from Table 2 that $U$ Deep shaped notch was most common shape followed by $\mathrm{J}$ shallow shaped notch. V Shallow shaped notch was seen in $14.87 \%$ of scapulae.

TABLE II: SHAPE OF THE NOTCH

\begin{tabular}{|c|c|c|c|c|}
\hline \multirow{2}{*}{$\begin{array}{l}\text { Shape of the } \\
\text { notch }\end{array}$} & \multicolumn{2}{|c|}{ Side } & \multirow{2}{*}{$\begin{array}{c}\text { No. of } \\
\text { Scapulae }\end{array}$} & \multirow{2}{*}{ Percentage $\%$} \\
\hline & $\mathrm{Rt}$ & $\mathrm{Lt}$ & & \\
\hline U Deep & 28 & 22 & 50 & $41.32 \%$ \\
\hline V Shallow & 11 & 07 & 18 & $14.87 \%$ \\
\hline J Shallow & 16 & 15 & 31 & $25.61 \%$ \\
\hline $\begin{array}{c}\text { W Double } \\
\text { Notch }\end{array}$ & 0 & 1 & 01 & $0.86 \%$ \\
\hline
\end{tabular}

Round edge at the depth of the notch was more common as compared to sharp edge (Table III).

\section{TABLE III: NATURE OF EDGE AT THE DEPTH OF THE NOTCH}

\begin{tabular}{|c|c|c|c|c|}
\hline \multirow{2}{*}{ Edges } & \multicolumn{2}{|c|}{ Side } & \multirow{2}{*}{$\begin{array}{c}\text { No of } \\
\text { Scapula }\end{array}$} & \multirow{2}{*}{ Percentage $\%$} \\
\hline & $\mathrm{Rt}$ & $\mathrm{Lt}$ & & \\
\hline Sharp & 27 & 26 & 53 & $43.80 \%$ \\
\hline Round & 29 & 28 & 57 & $47.10 \%$ \\
\hline
\end{tabular}

Transverse scapular ligament was fully and partially ossified in $16.52 \%$ of scapulae while fully ossified in $9.09 \%$ of scapulae.

\begin{tabular}{cccccc}
\multicolumn{4}{c}{ TABLE IV: OSSIFICATION OF THE TRANSVERSE SCAPULAR LIGAMENT } \\
\hline & \multicolumn{3}{c}{ Side } & $\begin{array}{c}\text { No of } \\
\text { Scapulae }\end{array}$ & Percentage \% \\
\cline { 2 - 5 } Ossification & RT & Lt & & 9 & $7.43 \%$ \\
\hline Partially ossified & 5 & 4 & 11 & $9.09 \%$ \\
$\begin{array}{c}\text { Fully Ossified } \\
\text { Total = Partially } \\
\text { ossified + fully } \\
\text { Ossified }\end{array}$ & 6 & 5 & & 20 & $16.52 \%$ \\
\hline
\end{tabular}

It can be seen from Table $\mathrm{V}$ that Mean upper transverse diameter of suprascapular 8 notch was $12.83 \mathrm{~mm}$ (12$22 \mathrm{~mm}$ ) while Middle Transverse diameter was $7.94 \mathrm{~mm}$ (10-16 mm). The depth of suprascapular notch was $9.41 \mathrm{~mm}$ (10-18 mm).

TABLE V: SHOWING TRANSVERSE DIAMETER AT UPPER AND MIDDLE PART

\begin{tabular}{ccc}
\multicolumn{3}{c}{ OF THE NOTCH AND DEPTH OF THE NOTCH } \\
\hline Diameter & Range $(\mathrm{mm})$ & Mean $(\mathrm{mm})$ \\
\hline $\begin{array}{c}\text { Upper Transverse diameter } \\
\text { Middle Transverse } \\
\text { Diameter }\end{array}$ & $12-22$ & 12.83 \\
Depth of the notch & $10-16$ & 07.94 \\
\hline
\end{tabular}

Mean Transverse Diameter of ossified foramen was $9.18 \mathrm{~mm}$ while vertical diameter was $9.63 \mathrm{~mm}$. (Table VI).

TABLE VI: OSSIFIED FORAMEN: TRANSVERSE AND VERTICAL DIAMETER

\begin{tabular}{ccc}
\hline Ossified foramen & Range $(\mathrm{mm})$ & Mean $(\mathrm{mm})$ \\
\hline Transverse Diameter & $9-15$ & 9.18 \\
Vertical Diameter & $10-15$ & 9.63
\end{tabular}

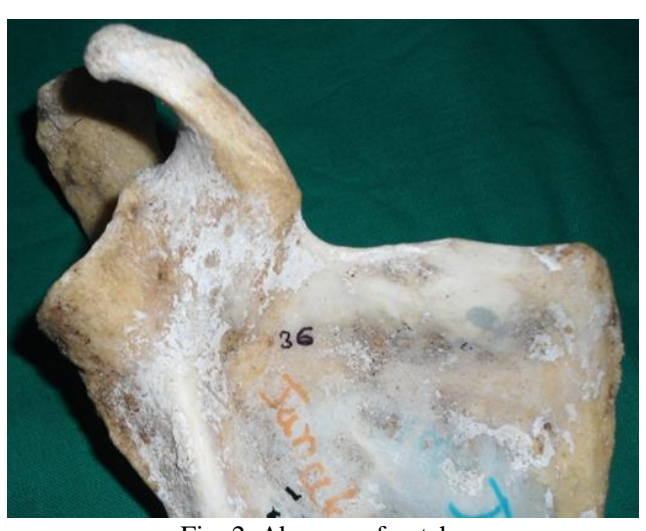

Fig. 2. Absence of notch.

Different shapes of suprascapular notch:

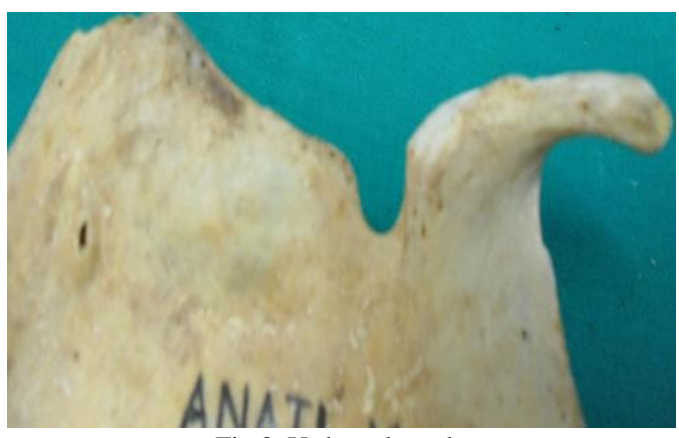

Fig.3. U shaped notch. 


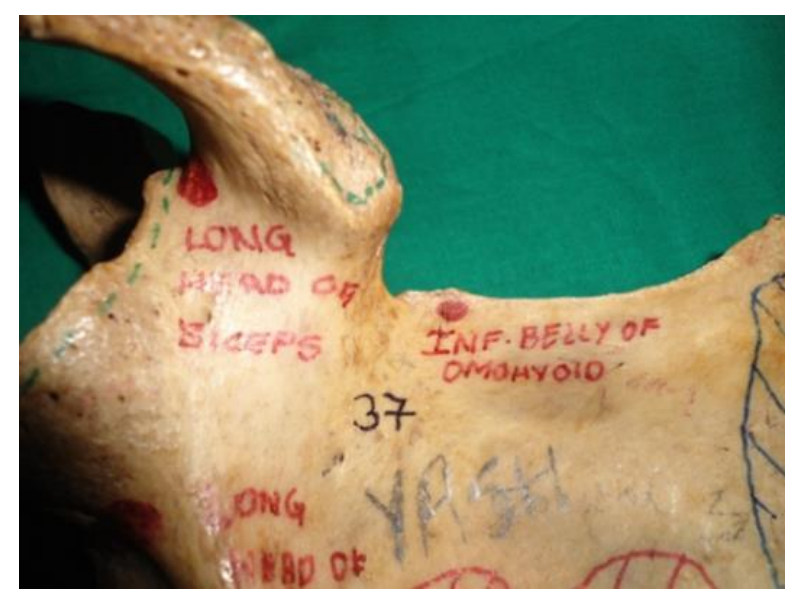

Fig.4. J shaped notch.

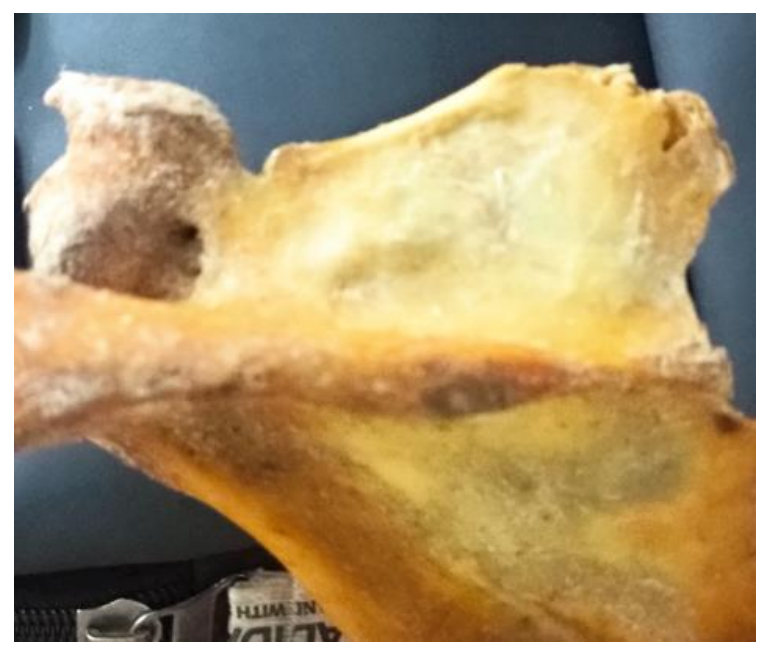

Fig.5. V shaped notch.

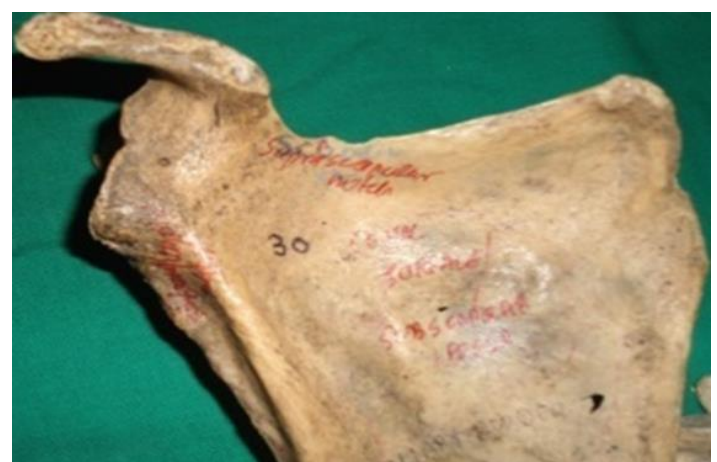

Fig. 6. W shaped notch.

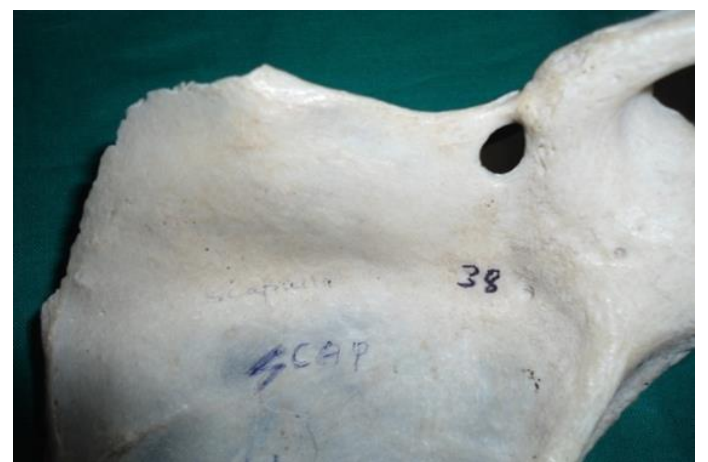

Fig.7. Fully ossified superior transverse scapular ligament.

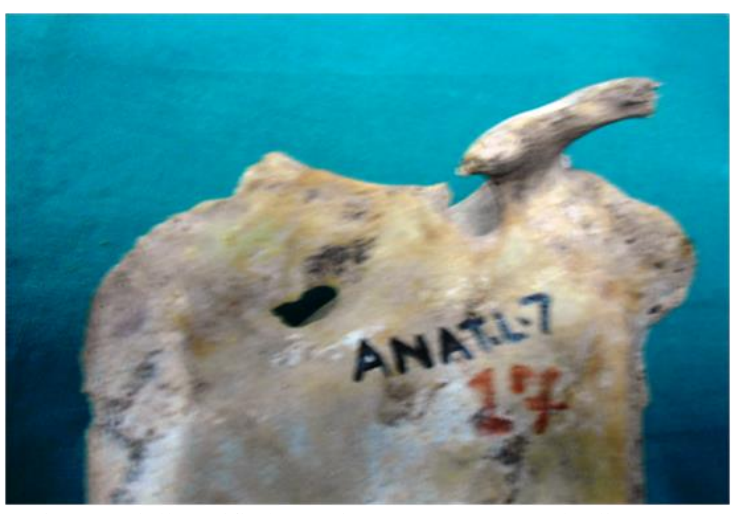

Fig.8.Partiallyossified superior transverse scapular ligament

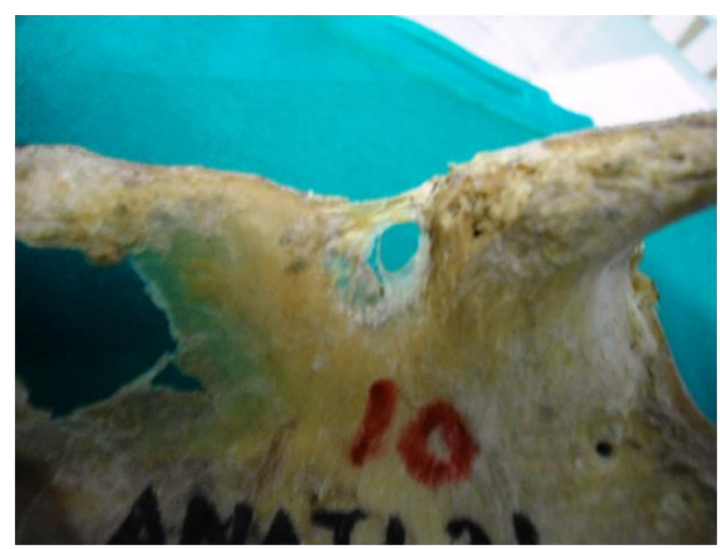

Fig. 9. suprascapular foramen showing vertical ligamentous band extending from one end of the transverse scapular ligament to the depth of the notch.

In one specimen suprascapular foramen was further narrowed by presence of vertical ligamentous band extending from one end of the transverse scapular ligament to the depth of the notch.

\section{DISCUSSION}

Previous researchers like Rangachari [4] classified the supra scapular notch into six types as well as the degree of ossification of superior scapular transverse ligament.

Type I [8\%]: Notch is absent. The superior border makes a wide depression from the medial angle to the coracoid process.

Type II [31\%]: Notch is blunted V-shape.

Type III [48\%]: Notch is U-shaped with nearly parallel margins.

Type IV [3\%]: Notch is V shaped and very small. A shallow notch is formed for the suprascapular nerve near to the notch.

Type V [6\%]: Notch is minimal and U- shaped with a partially ossified ligament.

Type VI [4\%]: Notch is a foramen as the ligament is completely ossified 4

Presence of suprascapular notch in present study was $82.65 \%$, U Kannan reported $80 \%$, Rubi Saika $82.56 \%$, Roopali et al. $73.6 \%$ Jadhav SD et al. $92.35 \%$ K Santosh et al. $97.4 \%$ so this is similar to the previous workers [11][15].

Different authors have observed different shapes of suprascapular notch in scapulae. In present study (Fig 3) U 
shaped notch was found in $41.32 \%$ the study was close to U Kannan et al. 52\% Rube et al $40.3 \%$ Roopaliet al. $40.6 \%$ Jadhav et. al. 39.79\% and Kumar Santosh et. al 37.5\%. But Khadija Iqbal and Rameez Iqbal found less incidence i.e., $14 \%$ [11]-[15], [6].

\begin{tabular}{|c|c|c|c|c|c|c|}
\hline $\begin{array}{l}\text { Shape of } \\
\text { notch }\end{array}$ & $\begin{array}{c}\text { U Kannan } \\
\text { et a l (2014) }\end{array}$ & $\begin{array}{c}\text { Rubi Saikiaet,al. } \\
\qquad(2017)\end{array}$ & $\begin{array}{l}\text { Roopaliet al. } \\
\text { (2017) }\end{array}$ & $\begin{array}{l}\text { Jadhav S.D. } \\
\text { et,al(2012) }\end{array}$ & $\begin{array}{c}\text { Kumar Santosh } \\
\text { et,al(2020) }\end{array}$ & $\begin{array}{c}\text { Present } \\
\text { study }\end{array}$ \\
\hline $\begin{array}{l}\text { Absence of } \\
\text { notch }\end{array}$ & $20 \%$ & $17.44 \%$ & $26.4 \%$ & $7.76 \%$ & $2.6 \%$ & $17.35 \%$ \\
\hline $\begin{array}{c}\text { Presence of } \\
\text { notch }\end{array}$ & $80 \%$ & $82.56 \%$ & $73.6 \%$ & $92.35 \%$ & $97.4 \%$ & $82.65 \%$ \\
\hline U Shaped & $52 \%$ & $40.3 \%$ & $40.6 \%$ & $39.79 \%$ & $37.5 \%$ & $41.32 \%$ \\
\hline V shaped & $10 \%$ & 0 & $17 \%$ & $19.38 \%$ & $29.4 \%$ & $14.87 \%$ \\
\hline J shaped & 0 & $21.31 \%$ & 0 & $20.66 \%$ & $18.75 \%$ & $25.61 \%$ \\
\hline W shaped & $\mathrm{O}$ & 0 & 0 & 0 & 0 & $0.86 \%$ \\
\hline Sharp edge & 0 & 0 & 0 & 0 & 0 & $43.80 \%$ \\
\hline $\begin{array}{l}\text { Rounded } \\
\text { edge }\end{array}$ & 0 & 0 & 0 & 0 & 0 & $47.10 \%$ \\
\hline $\begin{array}{l}\text { Partially } \\
\text { ossified }\end{array}$ & $4.1 \%$ & 0 & $2.8 \%$ & $4.84 \%$ & 0 & $7.43 \%$ \\
\hline Fully ossified & $10.1 \%$ & $3.1 \%$ & 8.5 & 0 & $5.3 \%$ & $9.09 \%$ \\
\hline
\end{tabular}

In present study (Fig. 5) V shaped notch was observed in $14.87 \%$ U Kannan et, al reported 10\%, Roopali et, al $17 \%$ Jadhav SD 19.38\% Kumar Santosh et al. 29.4\% [13]-[15]. The V shaped suprascapular notch is vulnerable to the abrasion and entrapment of suprascapular nerve due to the narrow base.

In present study (Fig. 4) J shaped notch was observed in $25.61 \%$ similar to this study Rubi Saikia et. al $21.31 \%$ Jadhav et. al $20.66 \%$ and Kumar Santosh et, al $18.75 \%$ was noticed above findings. So, the J shaped notch was second common type [12], [14], [15].

One unique variation of shape of scapula was $\mathrm{W}$ shaped found in $0.86 \%$ (Fig. 6).

It is evident from Table III nature of edge at the depth of the notch was(i) sharp edged notch $43.80 \%$ and(ii) rounded edge was $47.10 \%$ No one observed the edge of the notch. The narrow sharp edge of notch at the bottom of the suprascapular notch may predispose to the symptoms of entrapment of supra scapular nerve syndrome.

It is noticed from Table IV that partially ossified superior transverse scapular ligament was7.43\% (Fig. 8) similar to this U Kannan et al reported $4.1 \%$, Jadhav et al. $4.84 \%$, Desai R. R. et al. 5.82\% [11], [14], [7].

It is observed from Table IV fully ossified superior transverse scapular ligament was $9.09 \%$. (Fig. 7). similar to this U kannan reported10\%, Rubi Saikia et al 3.1\%, Roopali et al $8.5 \%$ and Kumar Santosh et al 5.3\%. This was close to U Kannan et al.Roopali et.al. [11]-[13], [15]. Zahid A et al. found $1.96 \%$ [8]. Saikia et al and Zahid A et al. found less incidence. In present study the diameter of suprascapular notch variedin the upper part $12.83 \mathrm{~mm}$ (range 12-22 $\mathrm{mm}$ ), middle part $07.94 \mathrm{~mm}(10-16 \mathrm{~mm})$ anddepth of notch $09.41 \mathrm{~mm}$ (range 10-18 mm (Fig. 1) (Table V). M. Polguj et al. did the retrospective study of CT scan of the shoulders. They analyzed the suprascapular region and mentioned the types of suprascapular notch by measuring diameter at upper part, middle part, and vertical diameter. They observed the transverse diameter at the upper and middle part of notch was $8.62 \mathrm{~mm}$ and $10.03 \mathrm{~mm}$ respectively. The vertical diameter was7.53 $\mathrm{mm}$ [20].

Kothandaraman $\mathrm{U}$ and Lokanadha $\mathrm{S}$ found bony prominence within the suprascapular notch and its percentage was $3.5 \% 10$.

Measurement of the ossified foramen was transverse diameter $9.18 \mathrm{~mm}$ (range 9-15 $\mathrm{mm}$ ).

In fully ossified and partially ossified suprascapular notch converted into foramen and reduced all diameter which may compress the suprascapular nerve and gives rise to suprascapular never entrapment syndrome. Suprascapular nerve entrapment neuropathy may occur in the supra scapular notch. The sharp edge at the bottom of the notch may be contributing factor. The suprascapular nerve may be damaged due to the trauma to the scapula and shoulder there is pain in shoulder and wasting and weakness of supraspinatus and infraspinatus [16]. suprascapular nerve arises from the upper trunk of brachial plexus. It lies in the posterior triangle of neck; it passes under the omohyoid muscle and anterior border of trapezius to enter scapular notch and passes below the superior scapular transvers ligament it enters supraspinous fossa and supply the supraspinatus muscle. Then it enters infraspinous fossa through spino-glenoid notch, here it supplies the infraspinatus muscle. It also gives the branches to the shoulder joints. The nerve may entrap at suprascapular notch due to the narrowing of neck by cyst. Ossification of superior scapular transverse ligament, fracture of scapula at spino-glenoid notch, due to this reason vague pain radiating across the scapula, dull shoulder ache, limited movement of shoulder joint wasting of supraspinatus and infraspinatus muscles [19].

Suprascapular neuropathy is a big problem in individual who have been involved in overhead abduction [14] the 
morphological variation of suprascapular notch is not clear but Odita J. C. et. al. [18] stated that the ossification of the coracoid process epiphysis influences the shape of suprascapular notch. The variation of the notch gives rise the suprascapular nerve entrapment syndrome [17].

\section{CONCLUSION}

The knowledge of suprascapular notch variations is of great importance for surgeons performing suprascapular nerve decompression especially by means of endoscopic techniques. Our anatomical study helps the clinicians before planning a surgery.

\section{REFERENCES}

[1] Williams P. L., Bannister L. H., Bery M. M., Collins P., Dyson M., DussekJ. E., "Gray's anatomy". 38th ed. Edinburgh:Churchil Livingstone; 1995.

[2] Mestdagh M, Drizenko A, Ghestem P. "Anatomical basis of suprascapular nerve syndrome”. AnatClin. 3: (2) 67-71,1981.

[3] Kopell H. P., Thompson WAL (1959) "Pain and the frozen shoulder".SurgGynecolObst, 109:92-96.

[4] Rengachary S. S., Burr D., Lucas S., Hassanein K. M., Mohn M. P., Matzke H. "Suprascapular entrapment neuropathy: a clinical, anatomical, and comparative study". Part 2: Anatomical study. Neurosurgery. 5: 447-451, 1979

[5] Biglani L. U., Dalsey R. M., MCCann P. D., April E. W. "An anatomical study of suprascapular nerve.Arthroscopy";6:301-305 1990.

[6] Iqbal K, Iqbal R. "Classification of Suprascapular Notch According to Anatomical Measurements Morphological Classification and Variations in Supra Scapular Notch of Human Scapula”.2011, Vol. 21 (3): 169-170.

[7] Desai R, Ambali MP, and Doshi MA. "Incidence of ossification of superior transverse scapular ligament of scapula in Indian population”. Int.J.Curr.Microbiol.App.Sci 3(9) 1081-1084,2014.

[8] Zahid A, Khan MW, Khan. "Ossified superior transverse scapular ligament and morphological study on dried Pakistani scapulae" $2014 ; 30$ (3): 1-4

[9] Desai U. "Complete Absence of suprascapular notch in dried human scapulae in Gujarat". 2014, Vol: 3(8): 2277 - 8179

[10] Kothandaraman U. and Lokanadham S. "Morphological classification and variations in suprascapular notch of human" 2014 (3) :452-455.

[11] Kannan U Kannan N.S, Anbalagan J. "Morphometric study of suprascapular notch in Indian dry scapulae with specific reference to the incidence of completely ossified superior transverse scapular ligament of clinical and diagnostic research". 2014 Mar, Vol-8(3): 7 10 .

[12] Saikia R, Baishya RJ, Deka B. "Variations in the Shape of the suprascapular notch in dry human scapula: an anatomical study", 2017, Vol. 5, (1), 187-190.

[13] Nikumbh R.D, Nikumbh D.B. Wanjari A.N. "Morphological variations of the suprascapular notch clinical relevance in suprascapular neuropathy VIS-A-VIS Ossified superior transverse scapular ligament", 2017, Vol 5(3.1):4168-72. ISSN 2321-4287.

[14] Jadhav, S. D. "The suprascapular notch: Its various shapes in Indian dry scapula”, Res. J. Pharm. Biol. Chem. Sci.,2012, 3(4):1085-90.

[15] Kumar S and Maharshi A. "A morphological study of suprascapular notch in human dry scapulae in population of Rajasthan", IJARR, 5(1), 2020; 18-22

[16] Gray H, Standring S, Ellis H, Gray, s anatomy "The anatomical basis of clinical practice", 39th ed. Edinburgh: Elsevier Churchill Livingstone; 2005 page no-847.

[17] Chhabra N, Prakash S,Ahuja MS. "Morphometry and morphology of suprascapular notch: it's importance in suprascapular nerve entrapment”. Int J Anat Res 2016;4(3):2536-2541.

[18] Odita J. C., Ugbodaga J. A., Okolo A. A. "Humeral head and coracoid ossification in Nigerian new born infants", Paediatric Radio.1983;13:276-8.

[19] Jacob P. J., Arun K, Binoj R. "Suprascapular Nerve entrapment syndrome”. Kerala Journal of Orthopaedics 2012;25: (I) 21-24.
[20] Polguj M. \& Sibiński M. \& Grzegorzewski A. \& Grzelak P. \& Majos A. \&Topol M. "Variation in morphology of suprascapular notch as a factor of suprascapular nerve entrapment", International orthopaedics (SICOT) (2013) 37:2185-2192.

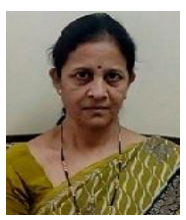

Dr. Mrs. Kamal D. Pawaris graduate (B.A.M.S) from Government AyurvedicMedical College, Nanded. Post graduate (Msc. Medical anatomy) fromPravara Institute of Medical Sciences, Deemed to be University, Loni. Teaching experience 6 years. Currently working as Tutor, Department of Anatomy, Rural Medical College, Loni, Maharashtra, India.

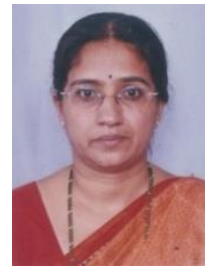

Dr. Mrs Sushama Kalidas Chavan is graduated from MGM Medical college, Aurangabad. Post graduate (MS Anatomy) from SRTR Medical college Ambajogai in the year (2000) She has worked in various institute and was professor and Head Pravara Institute of Medical Sciences, Rural Medical College, Loni. Maharashtra India. Presently she is working as Professor MIMER Medical College TalegoanDabhade, Pune, Maharashtra, India. She has 22 Research paper to her credit published in national and international Journals. Interested in research on Gross Anatomy, Histology, Anthropology. Has guided Post graduates in Anatomy, MSc Anatomy and PHD student.

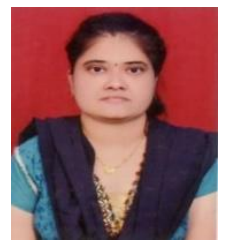

Dr. Mohini M. JoshiEducational Qualification M.B.B.S 1999, M. D. (Anatomy) June2010working as Professor in Anatomy at Pravara institute of Medical Sciences, RuralMedical College Loni, Maharashtra, India. Teaching Experience in Anatomy is of sixteen years.Eighteen papers were published in various national and international journals. Fifty workshops have attended. Interested in doing research in Histology and NeuroAnatomy. 